(C) Д.Б. Домбровський, Ю.В. Оліник, 2020

УДК 616.14-007.64-002.44-036.1-085.27

\title{
Використання клітинних технологій у комплексному лікуванні паціснтів із трофічними венозними виразками
}

\author{
Д.Б. Домбровський, Ю.В. Оліник
}

Буковинський державний медичний університет, кафедра хірургї №1; Чернівецька обласна клінічна лікарня, відділення хірургії судин, Чернівиі

\section{Реферат}

Враховуючи масштабність та розповсюдженість захворювання в людській популяції, пошук нових і доповнення існуючих методів комплексного лікування трофічних виразок нижніх кінцівок $є$ актуальним питанням сучасної медицини. Завдяки величезній біологічній цінності кордової крові ії розглядають, як джерело стовбурових клітин на рівні $з$ іншими джерелами. Метою роботи було оцінити та порівняти результати лікування хворих із хронічною венозною недостатністю нижніх кінцівок, ускладненою трофічною виразкою, резистентною до стандартної терапії після трансплантації стовбурових клітин кордової крові та без неї. Пацієнтам, які в анамнезі перенесли оперативні втручання по корекції венозної гіпертензії, мали виразковий дефект не менше 2-х років на тлі базисної терапії під епідуральною анестезією пункційно під виразку вводилась клітинна суспензія. Індекс швидкості загоєння визначали за формулою Попової у модифікації Гірка Е.І., Кравцова С.А. У результаті проведеного дослідження встановлено, що процес загоєння у пацієнтів дослідної групи розпочинався з перших діб після трансплантації зі зменшення периульцелярного набряку та запальної гіперемії м'яких тканин навколо виразки, майже не залишається «мінус тканини», грануляції спочатку активно наростають, піднімаючи дно виразки до рівня дерми, а далі процес загоєння, в основному, відбувався за рахунок крайової епітелізації. Індекс швидкості загоєння виразкового дефекту у пацієнтів дослідної та контрольної груп різнився протягом усього періоду спостереження і у пацієнтів після трансплантації стовбурових клітин кордової крові у 1,5-2 рази вище ніж у пацієнтів, яким проводилась стандартна консервативна терапія. Трансплантація клітин кордової крові призводить до активації власних регенеративних резервів організму та впливу на різні ланки патогенезу розвитку трофічних виразок венозного генезу, що зі свого боку прискорює загоєння виразкового дефекту.

Ключові слова: трофічна виразка, кордова кров, індекс загоєння.

The use of cell technologies in the complex treatment of patients with venoustrophic ulcers D.B. Dombrovskyi, Yu.V. Olinyk

Higher State Educational Establishment of Ukraine Bukovinian State Medical University, Surgery Department №1; Chernivtsi Regional Clinical Hospital, Department of Vascular Surgery

\begin{abstract}
The high prevalence of the disease in the population, the need to search for new and improve existing methods of complex treatment of lower extremity trophicul cers made it a topical issue of modern medicine. Due to the enormous biologicalvalue of cord blood, it is regarded as one of the main stemcellsources. The aim of this study was to evaluate and compare the results of treatment of patients with chronic venousin sufficiency of the lower extremities, complicated by trophiculcer, resistant to standard therapy after and without cord bloodstemcell transplantation. Patients who had a history of surgical intervention for the correction of venous hypertension had a nulceratived efect of at least 2 years on the background of basic therapy under epidural anesthesia punctually under the ulcercell suspension was injected. The healingrate index was determined by Popova's formula in the modification of Girka E.I., Kravtsova E.A. The healingprocess in the patients of the main group began on the first day after transplantation with the reduction of pericellulare demaand in flammatory hyperemia of the soft tissues around the ulcer, almost no "minustissue" was observed, granulation initially actively built up, raising the bottom of the ulcer dermal level, and the nthehealing process was mainly due to marginal epithelialization. The healingindex rate of the ulcer defectin the main and control groups varied throughout the observation period and in patients after cord blood stemcell transplantation was 1.5-2 times higher than in patients treated with standard conservative therapy. Cord blood cell transplantation leads to activation of the body's own regenerative reserves and influences the various pathogens chains of the development of venous trophic ulcers and acceleratesit's healing.
\end{abstract}

Key words: Trophic ulcer, cord blood, healing index.

Вступ. Венозна гіпертензія є основним чинником розвитку трофічних порушень та ініціює цілий каскад патологічних реакцій на субклітинному, клітинному та тканинному рівнях. За даними літератури, в США та країнах Західної Європи захворюваність на трофічні виразки трапляються у 40-60 осіб на 1000 населення і більше 70\% з них викликані венозною гіпертензією. У Великій Британії щороку витрачають 300-400 мільйонів фун- тів стерлінгів на лікування даної патології [1]. За даними наукового дослідження «ДЕТЕКТ», проведеного на базі Національного інституту хірургії та трансплантології ім. О.О. Шалімова, під впливом консервативної терапії тривалістю до чотирьох місяців, загоєння венозних трофічних виразок відбувається лише в $50 \%$ випадків. Після двох років лікування не загоюється $20 \%$, після п'яти років $-8 \%$ виразок залишаються відкритими. Згід- 
но $з$ рекомендаціями Товариства судинної хірургї та Американського венозного форуму (2014) у разі безуспішності традиційного місцевого лікування венозних виразок упродовж 4-6 тижнів, якщо площа виразки зменшується менш ніж на 30\%, лікар повинен розглянути можливість додаткового лікування [2]. У дослідженні М. Perrin та A.A. Ramelet (2011) доведена ефективність веноактивних препаратів у лікуванні хронічної венозної недостатності, проте патогенез розвитку та загоєння вивчений недостатньо [3]. Враховуючи масштабність і розповсюдженість захворювання в людській популяції, пошук нових та доповнення існуючих методів комплексного лікування трофічних виразок нижніх кінцівок $є$ актуальним питанням сучасної медицини [4]. Завдяки здатності диференціюватися в різні типи клітин все частіше науковці всього світу звертають свою увагу на можливість використання клітинних технологій в лікуванні нозологій, які погано піддаються терапії існуючими методами. Завдяки величезній біологічній цінності кордової крові іiі розглядають як джерело стовбурових клітин на рівні 3 іншими джерелами: кістковим мозком, периферійною кров'ю, плацентою, жировою тканиною та іншими. Основними перевагами саме кордової крові $\epsilon$ : висока доступність (у світі більше 200 млн. пологів на рік), проліферативна здатність у 10 разів вища, ніж у аналогічних клітин дорослої людини, відсутність ризику для здоров'я матері та дитини при заборі матеріалу, можливість використання аутологічного матеріалу (відсутність реакції "хазяїн проти трансплантата"), кількість стовбурових клітин у кордовій крові в 12 разів перевищує їхню кількість у кістковому мозку. 32013 року наказом MO3 України № 603 медична спільнота України, перша на пострадянському просторі, офіційно отримала право на трансплантацію стовбурових клітин людини при ішемії кінцівок, патологіях підшлункової залози, травмах та опіках.

Мета дослідження: оцінити та порівняти результати лікування хворих із хронічною венозною недостатністю нижніх кінцівок, ускладненою трофічною виразкою, резистентною до стандартної терапії після трансплантації стовбурових клітин кордової крові та без неї.

Матеріали та методи. Аналіз доклінічного експериментального етапу дослідження, проведеного на білих лабораторних лінійних щурах, дозволив перейти до наступного - клінічного етапу, для якого було відібрано 16 пацієнтів із трофічними виразками венозної етіології. Всі хворі отримували стаціонарне лікування в умовах відділення хірургії судин ОКУ «Чернівецька обласна клінічна лікарня» у період з 2015-2018 роки. Критерієм відбору були пацієнти, які в анамнезі вже перенесли оперативні втручання по корекції венозної гіпертензії, якщо такі були показані, а також час існування виразкового дефекту не менше 2-х років на тлі базисної терапії в стаціонарних та амбулаторних умовах. Розміри хронічних венозних виразок були від $3,5 \times 3,0$ см до $8 \times 10 \mathrm{~cm}$ діаметром та від $0,5 \mathrm{~cm}$ до 1,5 см глибиною. Локалізація ранових дефектів шкіри була по медіальній та латеральній поверхнях нижньої та середньої третин обох гомілок. Групу дослідження склали 7 пацієнтів, яким на тлі базисної терапії підепідуральною анестезією пункційно під виразку вводилась клітинна суспензія 3 наступними параметрами: вміст ядровмісних клітин - 0,11×10 9 до 3,7×10 9, кількість мононуклеарів - 15-60\%, КУО-ГМ - $(50 \pm 10) \times 10$ 3/мЛ, вміст гемопоетичних клітин, що несуть на своїй поверхні маркери CD34+ CD45+ та CD117+ CD45+, дорівнював відповідно $(0,85 \pm 0,20)$ та $(1,52 \pm 0,39) \%$. Життєздатність клітин - $(80 \pm 10 \%)$. Далі на 5-у, 14-у та 28-у добу пацієнтам проводились заміри діаметра та об’єму трофічної виразки для визначення індексу швидкості загоєння за формулою Попової у модифікації Гірка Е.I., Кравцова Є.А. (патент 68649 «Спосіб визначення швидкості загоєння ран»). Поставлена задача вирішується в способі визначення швидкості загоєння рани, шляхом математичного розрахунку, що включає визначення певного інтервалу часу, згідно 3 винаходом, визначають величину об'єму рани в даний момент і величину об'єму рани через визначений інтервал часу і за формулою розраховують індекс загоєння рани: $\left(\mathrm{V}-\mathrm{V}_{1}\right)$ Індекс $=\times 100 \%, \mathrm{~V} \times \mathrm{T}$, де $\mathrm{V}-$ величина об'єму рани в даний момент; $\mathrm{V}_{1}$ - величина об'єму рани через визначений часовий інтервал (Т) T число днів між першим і наступним вимірами. Визначення зміни об'єму рани є більш точним методом визначення швидкості загоєння ран, що дозволяє краще оцінювати динаміку ранового процесу i, отже, більш якісно лікувати рани. Для зручності розрахунків вважають, що глибокі рани (глибина більш 0,5 см) мають форму півсфери або напівеліпсоїду і їхній об'єм розраховують за формулами: Об'єм півсфери=2/3 $\mathrm{pr}^{2}$, де $\mathrm{r}$ - радіус кулі. Об'єм напівеліпсоїду $=2$ pabc, де a i b - півосіеліпса, c - висота (глибина рани). Запропонована формула дозволяє точно оцінити динаміку ранового процесу i, проводити більш якісне місцеве лікування [5].

Групу контролю склали 9 пацієнтів, які отримували стандартну консервативну терапію: венотоніки, антибіотики (після визначення чутливості), місцево щоденні перев'язки 3 вологовисихаючими пов'язками з антисептиками та еластична компресія, адже згідно 3 Рекомендацією European Wound Management Association (EWMA) щодо проведення компресійної терапії (Management of patients with venous legulcers: Challengesand Current Best Practice, 2016) компресійна терапія $\epsilon$ першим важливим кроком у лікуванні венозних виразок [6].

Результати досліджень та їх обговорення. У результаті проведеного дослідження встановлено, що процес загоєння у пацієнтів дослідної групи розпочинався 3 перших діб після трансплантації зі зменшення периульцелярного набряку та запаль- 
ної гіперемії м'яких тканин навколо виразки. Зменшення ексудації ранової поверхні відбувалось вже з 3-ї доби, коли в групі контролю фаза ексудації продовжувалась до 7-10 доби лікування. Появу активних грануляцій на дні виразкових дефектів бачили вже з 5-ї доби у пацієнтів, що перенесли трансплантацію стовбурових клітин кордової крові. Аналогічну картину у пацієнтів 3 базисною терапією спостерігали лише після 14-ї доби. Протягом перших 7-10 діб після трансплантації, завдяки стимуляції власних регенеративних можливостей організму, об'єм трофічних виразок значно зменшувався. Звертає на себе увагу той факт, що у пацієнтів дослідної групи майже не залишається «мінус тканини», грануляції спочатку активно наростають, піднімаючи дно виразки до рівня дерми, а далі процес загоєння, в основному, відбувався за рахунок крайової епітелізації, аж до повного загоєння виразок (рис. 1-4). У пацієнтів контрольної групи загоєння відбувається набагато повільніше 3 формуванням грубої нееластичної рубцевої тканини та збереженням «мінус тканини». Також слід відзначити значне зменшення больового синдрому у пацієнтів після трансплантації, що доводиться вдвічі меншою потребою у знеболюючих препаратах використаних в період стаціонарного лікування.

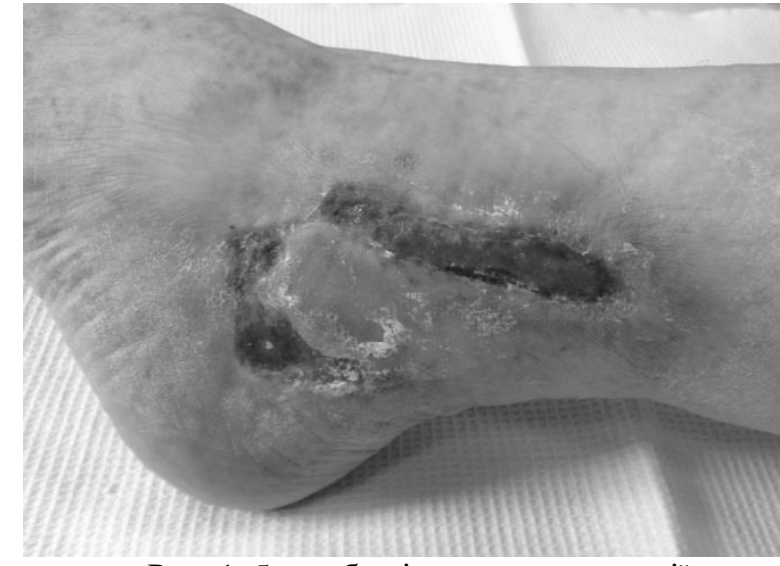

Рис. 1. 5-а доба після трансплантації.

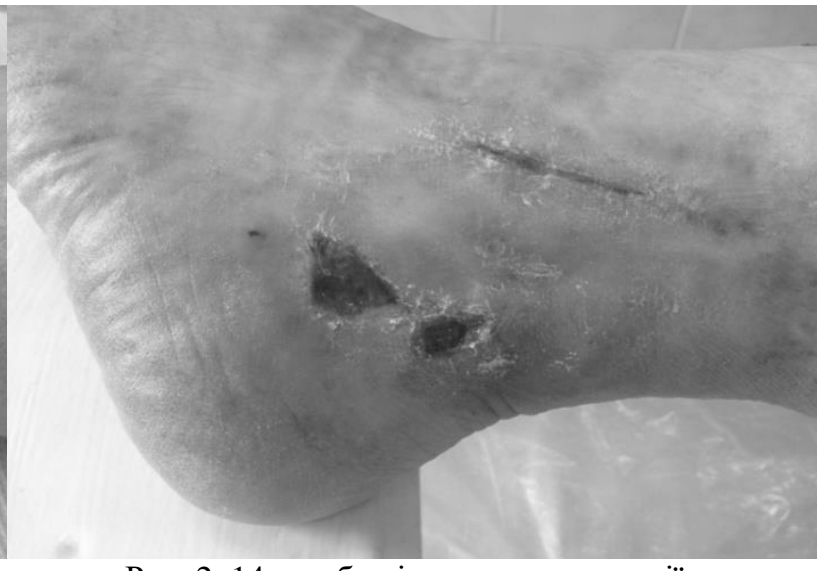

Рис. 2. 14-а доба після трансплантації.

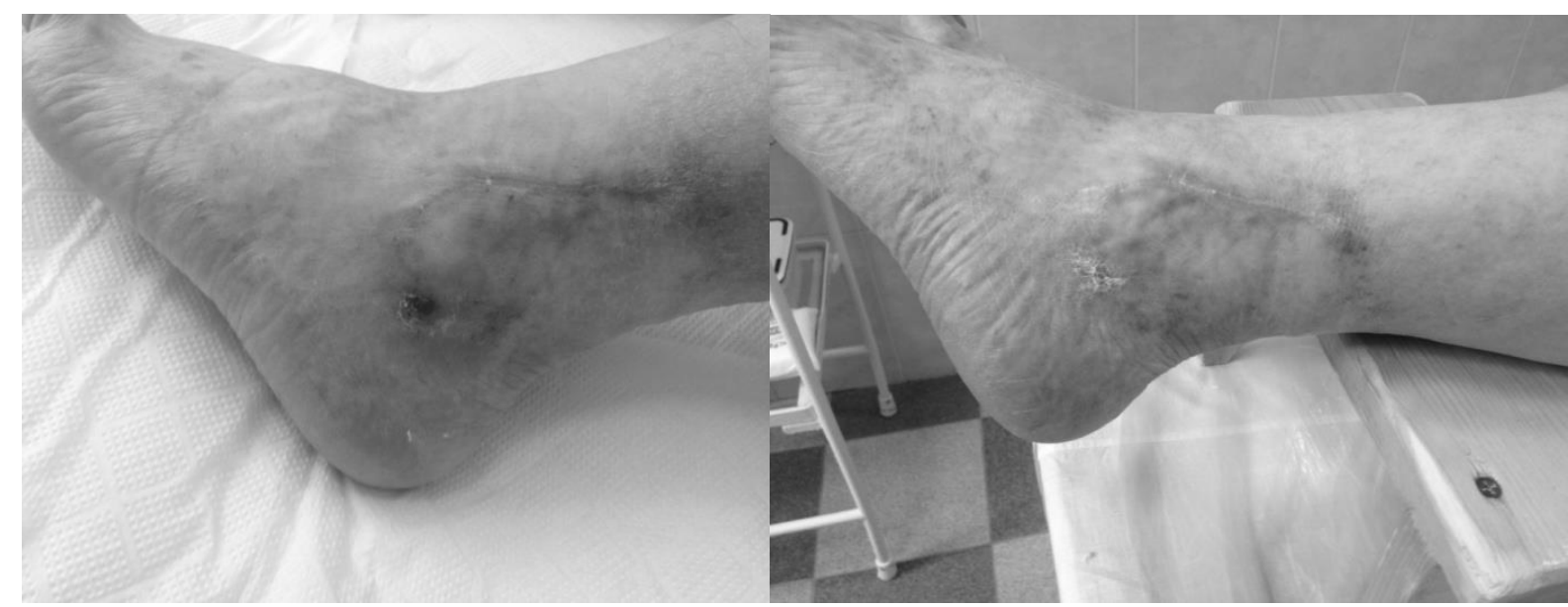

Рис. 3. 28-а доба після трансплантації.

Індекс швидкості загоєння виразкового дефекту у пацієнтів дослідної та контрольної груп різнився протягом усього періоду спостереження і у пацієнтів після трансплантації стовбурових клітин кордової крові у 1,5-2 разу вище ніж у пацієнтів, яким проводилась стандартна консервативна тера-
Рис. 4. 41-а доба після трансплантації.

пія. Також слід відзначити, що даний індекс швидкості був майже однаковим протягом усього періоду в пацієнтів контрольної групи, на відміну від дослідної групи, де швидкість одразу була вища та зростала до 14-ї доби, а потім поступово падала до 28-ї доби. 


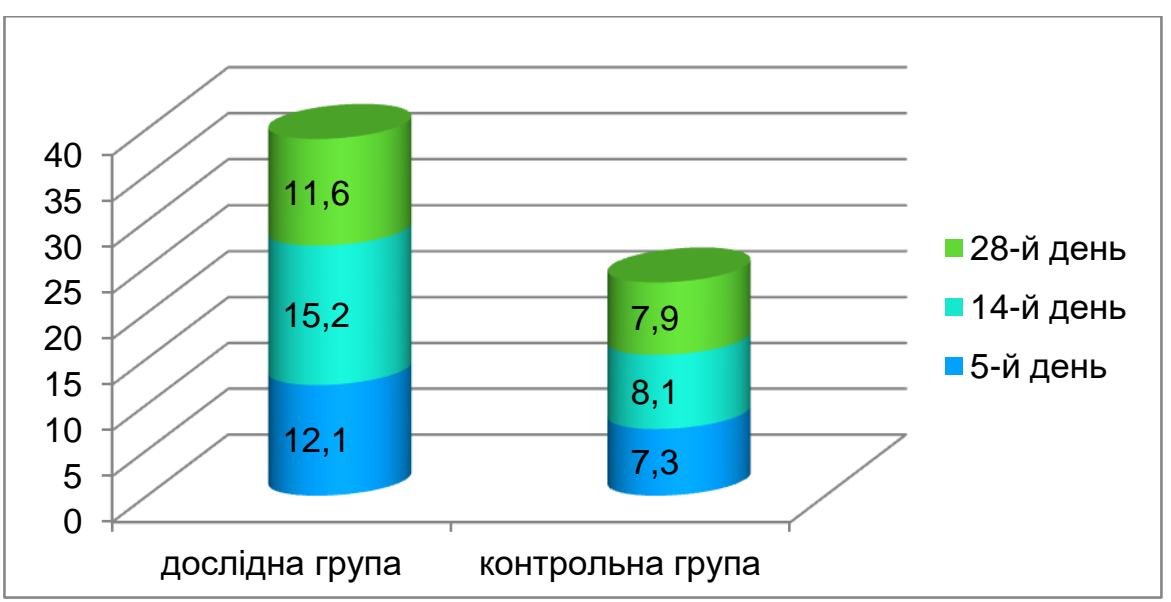

* різниця достовірна порівняно 3 контрольною групою $(\mathrm{p}<0,05)$.

Позитивний ефект від трансплантації стовбурових клітин кордової крові на якість та швидкість загоєння венозних трофічних виразок вбачаємо у впливі на різні ланки патогенезу розвитку виразкового ефекту, а саме: покращення мікроциркуляції внаслідок нормалізації функцій ендотелію, створення бар'єру стовбуровими клітинами для виходу форменних елементів крові, стимуляція ангіогенних процесів, вплив факторів росту клітин на процеси загоєння трофічної виразки та інші.

Висновки. Трансплантація клітин кордової крові приводить до активації власних регенеративних резервів організму та впливу на різні ланки патогенезу розвитку трофічних виразок венозного генезу, що у свою чергу прискорює загоєння виразкового дефекту.

Інформація про конфлікт інтересів. Автори заявляють про відсутність конфлікту інтересів при виконанні наукового дослідження та підготовці даної статті.

Інформація про фінансування. Автори гарантують, що вони не отримували жодних винагород у будь-якій формі, здатних вплинути на результати роботи.

Особистий внесок кожного автора у виконання роботи:

Домбровський Д.Б. - розробка концепції і дизайну дослідження, аналіз отриманих даних, редагування, статистична обробка даних;

Оліник Ю.В. - збір матеріалу дослідження, аналіз отриманих даних, підготовка тексту статті.

\section{Список використаної літератури}

1. Prevalence and ethiology of legul cersin Ireland / Brien J.F. etal. / Ir J. Med. Sci. 2010; 169(2): 110-2.

2. Даценко Б.М. Теория и практика местноголечениягнойных ран. К.: Здоров’я, 1995. 383 с.

3. Perrin M.,Ramelet A.A. Pharmacological treatment of primary chronic venous disease: rationale, results and unanswered questions / Perrin M., Ramelet A.A./Eur J VascEndovasc Surg.2011 Jan;41(1):117-25. Doi: 10.1016/j.ejvs.2010.09.025.

4. ManagementofPatientsWithVenousLegUlcers: ChallengesandCurrentBestPractice./ J WoundCare. 2016 Jun;25 Suppl 6:S1-S67. Doi: 10.12968/jowc.2016.25.Sup6.S1.

5. Clinical practice guidelines of the Society for Vascular Surgery (SVS) and the American Venous Forum (AVF) Management of venous legulcers / J VascSurg. 2014 Aug;60(2 Suppl):1S-2S. Doi: 10.1016/j.jvs.2014.04.058.

6. ЛяховськийВ.І.Особливості лікування та загоювання трофічних виразок нижніх кінцівок змішаного генезу/ В.І. Ляховський, О.М. Безкоровайний, А.В. СидоренкоКлінічна хірургія Klinichnakhirurhiia. 2019 July;86(7):36-41. DOI: 10.26779/2522-1396.2019.07.36.

Стаття надійшла до редакції: 23.12.2019 р. 